УДК 338.242 .2

DOI: https://doi.org/10.37320/2415-3583/8.3

Данілова Е.I.

кандидат економічних наук, доцент кафедри менеджменту зовнішньоекономічної діяльності підприємств, Національний авіаиійний університет

\title{
КОНЦЕПТУАЛЬНИЙ ПІДХІД ДО ФОРМУВАННЯ МЕТОДИЧНОГО ЗАБЕЗПЕЧЕННЯ ОЦІНЮВАННЯ ЕКОНОМІЧНОЇ БЕЗПЕКИ
}

Метою статті є формування концептуального підходу до оцінювання економічної безпеки підприємства, який, на відміну від наявних, базується на ідентифікаиії трьох складових частин економічної безпеки, а саме економічної безпеки використання потенціалу, економічної безпеки реалізації системи відносин з усіма зацікавленими особами та економічної безпеки умов діяльності; ідентифікачії об 'єктів оцінювання в кожній зі складових частин; виборі підходу до очінювання об'єктів складових частин; забезпеченні відповідності задач методу оиінювання. Запропонований кониептуальний підхід забезпечує систему управління інформацією про можливі напрями управління економічної безпекою на основі розрахунку узгодженості фактичного та ідеального показника рівня економічної безпеки. Реалізація запропонованої концептуальної моделі очінювання економічної безпеки підприємства формує практичний інструментарій для оиінювання трьох рівнів небезпек та ризиків, а саме ризиків, обумовлених результатами використання ресурсів; ризиків, обумовлених результатами реалізаиії системи взаємовідносин, які реалізуються в проиесі виконання функиій; ризиків, не залежних від результатів діяльності підприємства (зовнішніх та внутрішніх неконтрольованих ризиків). Узагальнено об'єкти та мету оцінювання відповідно до сутності поняття «економічна безпека». Сформовано та розкрито змістовну сутність приниипів оиінювання економічної безпеки підприємства. Визначено задачі оцінювання економічної безпеки складових частин економічної безпеки.

Ключові слова: принцฺии, оцінювання, економічна безпека, концепція економічної безпеки.

Постановка проблеми. Метою функціонування системи економічної безпеки є своєчасне виявлення небезпек і ризиків та запобігання їм шляхом забезпечення ресурсами, безпечного виконання функцій та вжиття комплексу заходів щодо попередження негативного впливу зовнішніх та неконтрольованих ризиків. Все це забезпечує досягнення мети системи економічної безпеки, основним критерієм якої є формування умов для стійкого, ефективного та динамічного розвитку.

У системі управління економічною безпекою оцінювання іiі стану та небезпек і ризиків як джерел впливу на його зміни формує фундаментальне підгрунтя для прийняття зважених та об'єктивних управлінських рішень.

Аналіз останніх досліджень i публікацій. Вирішення проблеми формування методичного забезпечення оцінювання економічної безпеки знайшло своє відображення в наукових працях вітчизняних та іноземних учених [1-10]. Кожен із науковців, роблячи відповідний внесок у розвиток теорії та методики оцінювання економічної безпеки, пропонує власне бачення підходів до ії оцінювання, однак їх більшість базується на ресурсно-функціональному, результативному або ризикоорієнтованому підході. 3 огляду на сутність поняття системи економічної безпеки, іiї оцінювання має базуватись на доцільному та цілепідпорядкованому поєднанні оцінювання ресурсів, функцій та ризиків діяльності, що забезпечується за умови формування комплексного методичного підходу до такого оцінювання.

Мета статті полягає у формуванні концептуального підходу до оцінювання економічної безпеки підприємства, який, на відміну від наявних, базується на ідентифікації трьох складових частин економічної безпеки, а саме економічної безпеки використання потенціалу, економічної безпеки реалізації системи відносин з усіма зацікавленими особами та економічної безпеки умов діяльності; ідентифікації об'єктів оцінювання в кожній зі складових частин; виборі підходу до оцінювання об'єктів складових частин; забезпеченні відповідності задач методу оцінювання. Запропонований концептуальний підхід забезпечує систему управління інформацією про можливі напрями управління економічної безпекою на основі розрахунку узгодженості фактичного та ідеального показників рівня економічної безпеки.

Виклад основного матеріалу. В системі управління економічною безпекою оцінювання стану економічної безпеки забезпечує суб'єкт управління інформацією за джерелами можливих небезпек, що дає змогу спрямувати управлінські дії на попередження та зниження впливу небезпек на результати діяльності підприємства.

Оцінювання економічної безпеки має базуватись на чітко сформованому методологічному базисі, який у найбільш узагальненому вигляді можна сформувати у вигляді реалізації таких логічно впорядкованих етапів: 
1) визначення мети та завдань оцінювання (постановка цілей оцінювання);

2) формування принципів оцінювання, які забезпечують досягнення мети;

3) визначення об'єкта оцінювання;

4) вибір наукового підходу до оцінювання;

5) вибір методу оцінювання, адекватного меті та завданням;

6) формування показників відповідно до вибраного методу та мети оцінювання;

7) інтерпретація результатів оцінювання;

8) прийняття управлінських рішень.

Постановка мети оцінювання визначає спрямованість усього процесу оцінювання економічної безпеки. 3 огляду на розмаїття наукових досліджень щодо оцінювання економічної безпеки, їх узагальнення та систематизацію можна стверджувати, що метою оцінювання економічної безпеки в постановці сучасних дослідників $є$ :

- визначення стану зовнішніх та внутрішніх чинників, а також впливу їх змін на стійкість діяльності підприємства;

- ідентифікація джерел загроз, небезпек та ризиків реалізації системи економічних відносин, економічного потенціалу, корпоративних ресурсів підприємства.

Чітка постановка мети оцінювання економічної безпеки дає змогу здійснити вибір об'єкта оцінювання, сформувати відповідний науковий підхід та методичний інструментарій оцінювання економічної безпеки.

Економічна безпека підприємства визначатиметься відповідно до ідентифікованих об'єктів оцінювання з урахуванням того, що поняття економічної безпеки трактується авторами так:

- стан захищеності підприємства від сукупності зовнішніх та внутрішніх загроз $[1 ; 3 ; 5 ; 6]$;
- стан використання ресурсів та підприємницьких можливостей $[4 ; 7 ; 8]$;

- стан захисту економічних інтересів підприємства [4];

- умови функціонування [2];

- сукупність чинників, які забезпечують незалежність, стійкість, здатність до прогресу в умовах дестабілізуючих чинників [10].

Для кожного з визначених в економічній літературі об'єктів економічної безпеки повинна бути сформована мета оцінювання, яка деталізується в задачах як сформованих напрямах досягнення поставленої мети (табл. 1).

Отже, на основі дослідження подібності під час оцінювання різних об'єктів системи економічної безпеки виявлено, що серед усієї сукупності визначених у науковій літературі об'єктів економічної безпеки, економічно обгрунтованими та логічно впорядкованими $є$ економічний потенціал, економічні взаємовідносини та умови діяльності підприємства.

Формування методичного інструментарію на засадах його відповідності об’єкту та задачам дослідження має розпочинатися 3 постановки принципів, які визначають правила оцінювання визначеного об'єкта економічної безпеки.

Виходячи 3 базових методологічних основ процесу оцінювання, основними його принципами вважаємо принцип цільового призначення, принцип системності, принцип повноти, принцип кількісної визначеності, принцип адекватності, принцип критеріальної відповідності, принцип узгодженості. Змістовна сутність принципів оцінювання економічної безпеки представлена в табл. 2.

Наступним фундаментальним етапом, який забезпечує реалізацію вищезазначених принци-

Таблиця 1 - Об'єкти та мета оцінювання, визначені відповідно до сутності поняття «економічна безпека»

\begin{tabular}{|c|c|c|}
\hline $\begin{array}{c}\text { Об'єкт економічної } \\
\text { безпеки }\end{array}$ & Об'єкт оцінювання & Мета оцінювання \\
\hline Стан підприємства & $\begin{array}{l}\text { Зовнішні та внутрішні ризики, } \\
\text { які впливають на зміну стану } \\
\text { підприємства. }\end{array}$ & $\begin{array}{l}\text { Ідентифікація джерел ризиків та кількісний } \\
\text { вимір їх впливу на зміну стійкості, стабільності } \\
\text { та розвитку підприємства. }\end{array}$ \\
\hline $\begin{array}{l}\text { Економічні інтереси } \\
\text { підприємства } \\
\text { (економічні } \\
\text { взаємовідносини) } \\
\end{array}$ & $\begin{array}{l}\text { Ризики реалізації економічних } \\
\text { інтересів. }\end{array}$ & $\begin{array}{l}\text { Визначення системи економічних інтересів, } \\
\text { міри їх збалансованості, кількісне оцінювання } \\
\text { ризиків, які впливають на зміну стану } \\
\text { збалансованості економічних інтересів. }\end{array}$ \\
\hline $\begin{array}{l}\text { Корпоративні ресурси } \\
\text { та підприємницькі } \\
\text { можливості } \\
\text { (економічний } \\
\text { потенціал) }\end{array}$ & $\begin{array}{l}\text { Стан використання корпоративних } \\
\text { ресурсів та підприємницьких } \\
\text { можливостей. }\end{array}$ & $\begin{array}{l}\text { Аналітичне дослідження ефективності } \\
\text { використання всіх видів ресурсів підприємства та } \\
\text { визначення такого стану їх використання, за якого } \\
\text { досягається найвища стійкість підприємства та } \\
\text { забезпечуються тенденції розвитку. }\end{array}$ \\
\hline Умови діяльності & Ризики зміни умов діяльності. & $\begin{array}{l}\text { Ідентифікація ризиків та умов безпечної } \\
\text { діяльності, визначення їх параметрів і таких } \\
\text { співвідношень між ними, які забезпечують } \\
\text { досягнення мети діяльності підприємства. }\end{array}$ \\
\hline
\end{tabular}


Таблиця 2- Змістовна сутність принципів оцінювання економічної безпеки

\begin{tabular}{|l|l|}
\hline \multicolumn{1}{|c|}{ Принцип } & \multicolumn{1}{c|}{ Зміст принципу } \\
\hline $\begin{array}{l}\text { Принцип цільового } \\
\text { призначення }\end{array}$ & Процес оцінювання підпорядкований реалізації визначеної мети такого оцінювання. \\
\hline Принцип повноти & В процесі оцінювання повинні бути враховані всі характеристики об’єкта оцінювання. \\
\hline Принцип системності & $\begin{array}{l}\text { Оцінювання базується як на сукупності кількісно оцінених характеристик об’єкта } \\
\text { оцінювання, так і на системі взаємозв’язків між ними. }\end{array}$ \\
\hline $\begin{array}{l}\text { Принцип кількісної } \\
\text { визначеності }\end{array}$ & $\begin{array}{l}\text { Чинники (характеристики), які формують (визначають) безпеку, повинні мати } \\
\text { кількісну або якісну оцінку. }\end{array}$ \\
\hline $\begin{array}{l}\text { Принцип критеріальної } \\
\text { відповідності }\end{array}$ & $\begin{array}{l}\text { Показники оцінювання вибираються відповідно до сформованих критеріїв } \\
\text { економічної безпеки. }\end{array}$ \\
\hline $\begin{array}{l}\text { Принцип адекватності } \\
\text { Усі складові частини економічної безпеки мають оцінюватися у взаємозв’язку } \\
\text { з їх економічними процесами та явищами. Оцінка повинна бути реальною та } \\
\text { відповідати об’єкту оцінювання. }\end{array}$ \\
\hline Принцип узгодженості & Етапи, показники та результати оцінювання повинні бути узгоджені між собою. \\
\hline
\end{tabular}

пів оцінювання, є з'ясування сутності об'єкта оцінювання. Важливість такого уточнення обумовлена тим фактом, що, відповідно до проведеного семантичного аналізу сутності поняття економічної безпеки, розмаїття об’єктів оцінювання зумовлює необхідність використання різних процедурних дій (методик), які використовуються для реалізації мети визначення стану економічної безпеки підприємства.

Отже, в контексті дослідження можна стверджувати, що система економічної безпеки підприємства базується на економічній безпеці реалізації економічного потенціалу, економічній безпеці системи взаємовідносин та економічній безпеці умов діяльності.

Економічна безпека реалізації економічного потенціалу - це стан захищеності всіх видів ресурсів від ризиків зміни їх стану та структури, а також безпека реалізації потенційних природних, виробничих, науково-технічних, соціально-культурних можливостей підприємства, які забезпечують стійкість організаційної структури, розвиток усіх видів діяльності підприємства та збалансованість системи його економічних відносин.

Економічна безпека системи взаємовідносин це захищеність економічних інтересів підприємства в системі його відносин 3 усіма суб'єктами взаємодії (працівниками, споживачами, постачальниками, державою, акціонерами тощо).

Економічна безпека умов діяльності підприємства - це стан захищеності внутрішнього та зовнішнього середовища від небезпек та ризиків можливих втрат і збитків діяльності.

Термінологічне впорядкування понять об'єкта економічної безпеки дає змогу здійснити їх агрегацію на основі використання методу порівняння співвідношень загального й конкретного. Оскільки ресурси та підприємницькі можливості конкретним елементом більш загального поняття економічного потенціалу, економічні інтереси є основою формування системи взаємовідносин, а внутрішні та зовнішні ризики формують умови економічної діяльності, в контексті дослідження виокремлено три об'єкти економічної безпеки, такі як економічний потенціал, економічні інтереси та умови діяльності.

Розмаїття наявних підходів обумовлює не лише необхідність семантичного та морфологічного аналізу сутності поняття економічної безпеки, але й дослідження відповідності іiі методичного інструментарію меті та задачам формування, оцінювання та управління економічною безпекою, які випливають із сутності цього поняття.

Окрім того, в наукових публікаціях зустрічається неприпустима методологічна неточність щодо ідентифікації підходів до оцінювання економічної безпеки підприємства. Так, у більшості наукових публікацій періоду становлення наукового напряму економічної безпеки підприємства виокремлюються функціональний, індикаторний, експертний підходи до оцінювання економічної безпеки. Таке трактування наукових підходів неприпустиме 3 огляду на те, що не всі вони відповідають сутності поняття наукового підходу як способу отримання нових знань і методів вирішення завдань.

Відповідно до означеної тези концептуальними засадами методичного підходу до оцінювання економічної безпеки є такі концепти:

- економічна безпека, тобто такий стан використання економічного потенціалу (ресурсів), реалізації системи взаємовідносин, формування умов діяльності (захисту від системи небезпек та ризиків), який забезпечує можливості стійкого та динамічного розвитку підприємства;

- системність економічної безпеки та складність взаємозв'язків у системі, що обумовлює необхідність оцінювання економічної безпеки на основі використання комплексу методів, які реалізують визначені цілі оцінювання;

- оцінювання складових частин економічної безпеки на основі використання різних підходів 
(ресурсного, функціонального, ризикоорієнтованого), оскільки в основу складових частин економічної безпеки підприємства покладено об'єкти різної природи походження;

- методичний підхід до оцінювання економічної безпеки підприємства, що є комплексним поєднанням методів оцінювання виокремлених його складових частин (економічної безпеки використання потенціалу, економічної безпеки реалізації відносин, економічної безпеки умов діяльності);

- індекс економічної безпеки підприємства, що $\epsilon$ комплексним виразом економічної безпеки його складових частин;

- ступінь гармонізації економічної безпеки, що оцінює наближеність фактичного стану економічної безпеки до іiі ідеального виразу;

- порівняння фактичного та ідеального рівнів економічної безпеки, що дає змогу виявляти джерела невідповідності, детальний аналіз яких формує сукупність управлінських рішень в напрямі усунення невідповідностей та наближення фактичного стану економічної безпеки до їі ідеального стану.

Логічно-структурна схема запропонованої концепції представлена на рис. 1 .

Відповідно до виокремлених об'єктів економічної безпеки методичний підхід до іiі оціню- вання формується на основі методів оцінювання економічної безпеки реалізації потенціалу, економічних інтересів та умов діяльності, що обумовлює необхідність використання комплексного поєднання методів та показників їх оцінювання.

У запропонованій концептуальній моделі оцінювання економічної безпеки підприємства базується на оцінюванні трьох рівнів небезпек та ризиків, а саме ризиків, обумовлених результатами використання ресурсів; ризиків, обумовлених результатами реалізації системи взаємовідносин, які реалізуються в процесі виконання функцій; ризиків, не залежних від результатів діяльності підприємства (табл. 3).

Висновки. На основі поглибленого аналізу сутності понять економічної безпеки, наукових підходів до оцінювання економічної безпеки, методів оцінювання та їх відповідності задачам такого оцінювання виявлена невідповідність об'єктів економічної безпеки методичному підходу, який використовується для оцінювання їх безпеки, невідповідність назв наявних наукових підходів сутності поняття наукового підходу та методу, який покладено в основу такого оцінювання. На основі порівняльного аналізу сутності понять економічної безпеки й, відповідно, подальшого виокремлення об'єктів економічної безпеки виявлено, що економічна безпека - це стан без-

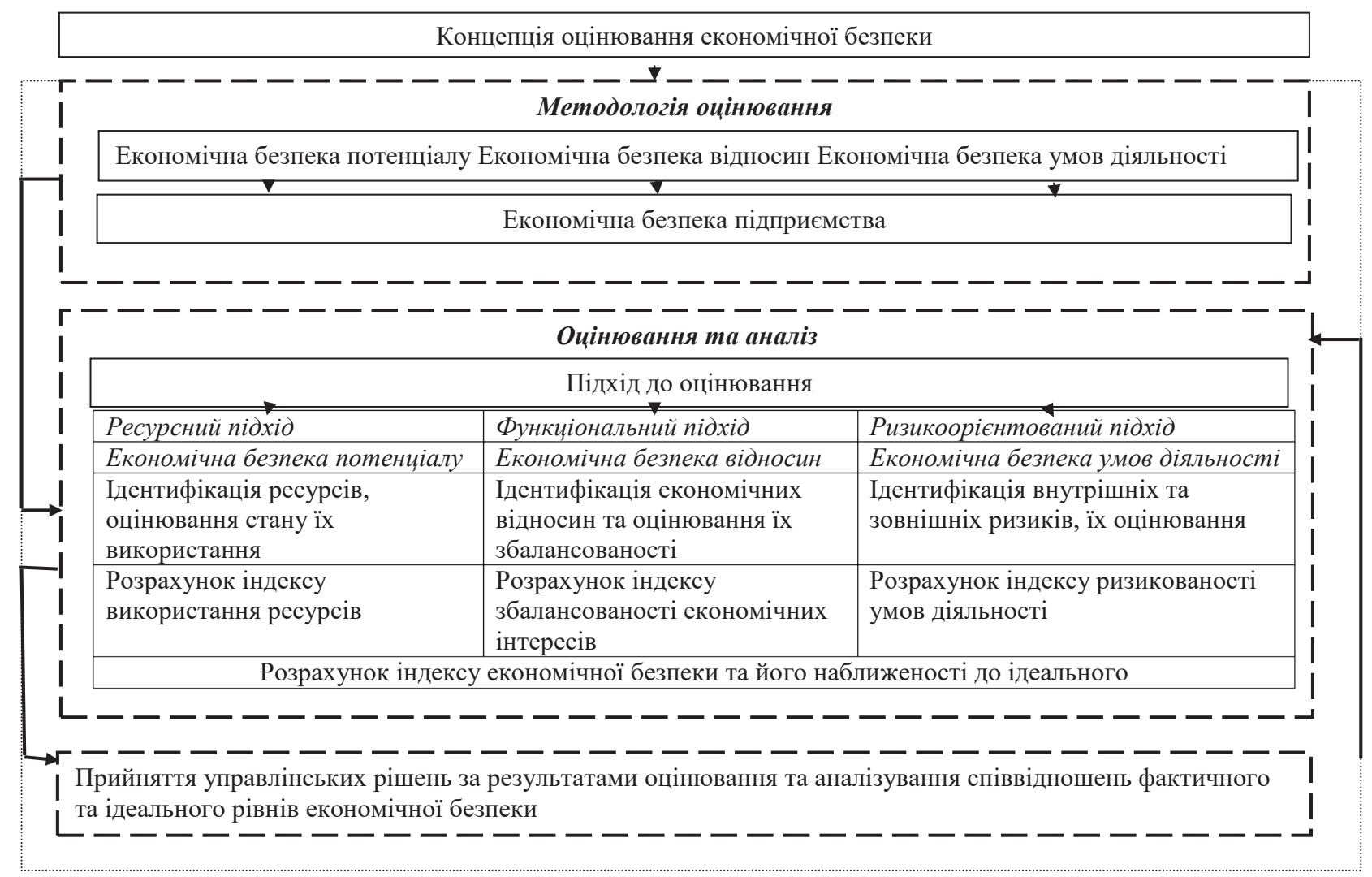

Рисунок 1 - Концептуальна модель оцінювання економічної безпеки підприсмства 
Таблиця 3 - Задачі оцінювання складових частин економічної безпеки

\begin{tabular}{|c|c|c|}
\hline $\begin{array}{c}\text { Складові } \\
\text { економічної безпеки }\end{array}$ & $\begin{array}{c}\text { Оцінювання економічної безпеки } \\
\text { за вихідними результатами діяльності }\end{array}$ & $\begin{array}{c}\text { Оцінювання економічної безпеки } \\
\text { за вхідними потоками небезпек } \\
\text { та ризиків }\end{array}$ \\
\hline $\begin{array}{l}\text { Економічна безпека } \\
\text { потенціалу }\end{array}$ & $\begin{array}{l}\text { Ідентифікація небезпек та ризиків у } \\
\text { використанні ресурсів підприємства. }\end{array}$ & \\
\hline Економічна безпека відносин & $\begin{array}{l}\text { Ідентифікація небезпек та ризиків } \\
\text { реалізації економічних інтересів усіх } \\
\text { зацікавлених осіб. }\end{array}$ & \\
\hline $\begin{array}{l}\text { Економічна безпека умов } \\
\text { діяльності }\end{array}$ & & $\begin{array}{l}\text { Ідентифікація зовнішніх і } \\
\text { неконтрольованих внутрішніх } \\
\text { небезпек та ризиків. }\end{array}$ \\
\hline
\end{tabular}

Джерело: розроблено автором

печного використання потенціалу підприємства, реалізації системи відносин та формування умов безпечної діяльності. Відповідно, об'єктами оцінювання економічної безпеки визнано три складові частини економічної безпеки підприємства, такі як економічна безпека потенціалу, економічна безпека взаємовідносин та економічна безпека умов діяльності.

Використання методу аналогій під час дослідження факторів та підходів до оцінювання виокремлених складових частин економічної безпеки дало змогу сформувати об'єкти оцінювання кожної складової частини, якими у складовій частині економічного потенціалу є ресурси, у складовій частині економічних відносин - функції, у складовій частині умов діяльності - внутрішні та зовнішні ризики. Все це дало підстави сформулювати тезу про відповідність кожного підходу до оцінювання визначеному об'єкту оцінювання.
Запропонована концепція оцінювання економічної безпеки базується на оцінюванні трьох складових частин економічної безпеки, а саме економічної безпеки використання потенціалу (ресурсів), економічної безпеки реалізації взаємовідносин, які виникають в процесі реалізації функцій, економічної безпеки умов діяльності, які змінюються під впливом ризиків діяльності.

Реалізація запропонованої концептуальної моделі оцінювання економічної безпеки підприємства формує практичний інструментарій для оцінювання трьох рівнів небезпек та ризиків, а саме ризиків, обумовлених результатами використання ресурсів; ризиків, обумовлених результатами реалізації системи взаємовідносин, які реалізуються в процесі виконання функцій; ризиків, не залежних від результатів діяльності підприємства (зовнішніх та внутрішніх неконтрольованих ризиків).

\section{Список використаних джерел:}

1. Васильців Т.Г., Волошин В.І., Бойкевич О.Р., Каркавчук В.В. Фінансово-економічна безпека підприємств України: стратегія та механізми забезпечення : монографія. Львів : Новий світ, 2012. 212 с.

2. Єфімова Г.В., Марущак С.М. Планування безпечного розвитку підприємства на основі результатів діагностики рівня його економічної безпеки. Економіка: реалії часу. 2013. № 3 (8). С. 43-49.

3. Зачосова Н.В. Формування системи економічної безпеки фінансових установ : монографія. Черкаси : ПП Чабаненко Ю.А., 2016, 375 с.

4. Зубко Т.Л. Методика визначення економічної безпеки підприємства. Економіка. Менеджмент. Бізнес. 2016. № 2. C. 69-76.

5. Ілляшенко С.М. Складові економічної безпеки підприємства і підходи до їх оцінки. Актуальні проблеми економіки. 2003. № 3. С. 12-19.

6. Кашин А.В. Экономическая безопасность предприятия: управленческие решения : автореф. дисс. ... канд. экон. наук : спец. 08.00.05 «Экономика и управление народным хозяйством» (экономическая безопасность). Москва, 2008.21 c.

7. Козаченко Г.В. Пономарьов В.П., Ляшенко О.М. Економічна безпека підприємства: сутність та механізм забезпечення. Київ : Лібра, 2003. 280 с.

8. Линник О.І., Артеменко Н.В. Стратегія економічної безпеки підприємства як фактор зменшення впливу зовнішніх та внутрішніх загроз. Вісник НТУ «ХПІ». 2013. № 67 (1040). С. 159-169.

9. Прус Н.В. Витрати опортуністичної поведінки в системі економічної безпеки підприємства. Управління проектами та розвиток виробництва : збірник наукових праць. № 4 (44). Луганськ : вид-во СНУ ім. В. Даля, 2012. С. $32-37$.

10. Фальченко О.О., Глушач Ю.С. Стратегія забезпечення економічної безпеки підприємств. Вісник НТУ «ХПI». 2013. № 66 (1039). C. 157-160.

\section{References:}

1. Vasyl’tsiv, T.H. Voloshyn, V.I., Bojkevych, O.R., Karkavchuk, V.V. (2012), Finansovo-ekonomichna bezpeka pidpryiemstv Ukrainy: stratehiia ta mekhanizmy zabezpechennia: monohrafiia [Financial and Economic Security of Ukrainian Enterprises: Strategy and Mechanisms of Provision: Monograph], Novyj svit, L'viv, Ukraine. 
2. Yefimova, H.V. and Maruschak, S.M. (2013), "Planning of safe development of the enterprise based on the results of diagnostics of the level of its economic security", Ekonomika: realii chasu, vol. 3 (8), pp. 43-49.

3. Zachosova, N.V. (2016), Formuvannia systemy ekonomichnoi bezpeky finansovykh ustanov : monohrafiia [Formation of economic security system of financial institutions : monograph], PP Chabanenko Yu.A., Cherkasy, Ukraine.

4. Zubko, T.L. (2016), "Methods for determining the economic security of the enterprise". Ekonomika. Menedzhment. Biznes, vol. 2, pp. 69-76.

5. Illiashenko, S.M. (2003), “Components of enterprise economic security and approaches to their assessment”. Aktual'ni problemy ekonomiky, vol. 3, pp. 12-19.

6. Kashyn, A.V. (2008), "Economic security of the enterprise: management decisions", Ph.D. Thesis, 08.00.05 Economy and management of the national economy (economic security), Moscow, Russian Federation.

7. Kozachenko, H.V. Ponomar'ov, V.P. and Liashenko, O.M. (2003), Ekonomichna bezpeka pidpryiemstva: sutnist' ta mekhanizm zabezpechennia [Economic security of the enterprise: essence and mechanism of providing], Libra, Kyiv, Ukraine.

8. Lynnyk, O.I. and Artemenko, N.V. (2013), "Enterprise economic security strategy as a factor in reducing the impact of external and internal threats", Visnyk NTU "KhPI”, vol. 67 (1040), pp. 159-169.

9. Prus, N.V. (2012), "Expenses of opportunistic behavior in the system of economic security of the enterprise", Upravlinnia proektamy ta rozvytok vyrobnytstva : zb. nauk. pr., vol. 4 (44), pp. 32-37.

10. Fal'chenko, O.O. and Hlushach, Yu.S. (2013), "Strategy for ensuring the economic security of enterprises", Visnyk NTU "KhPI", vol. 66 (1039), pp. 157-160.

Danilova Elvira

National Aviation University

\section{CONCEPTUAL APPROACH TO DEVELOPMENT OF METHODOLOGICAL SUPPLY OF EVALUATION OF ECONOMIC SECURITY}

In the system of economic security management, the assessment of its condition and risks, as sources of influence on its changes, forms a fundamental basis for making informed and objective management decisions. The aim of the article is to develop conceptual approach to the evaluation of enterprise's economic security that unlike existing approaches is based on: 1) identification of 3 components of economic security, particularly economic security of usage of potential, economic security of relation system with all interested parties and economic security of operational environment; 2)identification of objects of evaluation in every component; 3) choice of approach to the evaluation of components' objects; 4) ensuring compliance of tasks with a method of evaluation. The proposed conceptual approach ensures the management system with the information about possible directions for managing economic security on the basis of calculation of consistency of actual and perfect indicators of economic security level. Implementation of the proposed conceptual model of evaluation of enterprise's economic security forms a practical tool for the evaluation of three levels of hazards and risks: risks that caused by the results of use of resources, risks that are caused by implementation of relation system (risks incur during the exercise of functions), risks that do not depend on the results of operations of an enterprise (external and internal uncontrolled risks). Objects and aim of evaluation in accordance with the essence of "economic security" concepts are generalized. The substance of principles of evaluation of enterprise's economic security is formed and given. The tasks of evaluation of economic security and the components of economic security are determined. The proposed concept of economic security assessment is based on the evaluation of three components of economic security: use of potential (resources), implementation of relationships that arise in the implementation of functions, and conditions of activity that change under the influence of activity risks.

Key words: principles, evaluation, economic security, concept of economic security.

JEL classification: M21. 